RLINOIS GEOLOGICAL

SURVEY LIBRARY

STATE OF ILLINOIS

DEPARTMENT OF REGISTRATION AND EDUCATION

\title{
Palynology and Sedimentology of Holocene Deposits \\ in Southern Lake Michigan
}

James E. King Jerry A. Lineback

David L. Gross

ILLINOIS STATE GEOLOGICAL SURVEY Jack A. Simon, Chief Urbana, IL 61801 
Digitized by the Internet Archive in 2012 with funding from University of Illinois Urbana-Champaign 


\title{
PALYNOLOGY AND SEDIMENTOLOGY OF HOLOCENE DEPOSITS IN SOUTHERN LAKE MICHIGAN ${ }^{*}$
}

\author{
James E. King, ${ }^{1}$ Jerry A. Lineback, ${ }^{2}$ and David L. Gross ${ }^{2}$
}

\begin{abstract}
An examination of the fossil pollen in the sediment shows that the upper part of the Waukegan Member (Holocene) of the Lake Michigan Formation can be divided into four pollen assemblage zones on the basis of subtle changes in percentages of the dominant types of pollen and in total numbers of pollen grains per gram of sediment. Three of these zones are distinguished on the basis of the relative abundance of pine and oak pollen, and the fourth is characterized by a high percentage of ragweed pollen. Zone 1 , the oldest, has lower percentages of pine and higher percentages of oak than the other zones. The total pollen concentration in the sediment is highest in zone 1 . Zone 2 is distinguished from zone 1 by a lower concentration of total pollen. Zone 3 has the highest percentages of pine. Zone 4 is distinguished by high percentages of ragweed, a result of forest clearance for agriculture about $1840 \mathrm{~A}$.D.

On the basis of the ragweed increase, calculated sedimentation rates in southern Lake Michigan for the postsettlement period are $0.49 \mathrm{~mm} / \mathrm{yr}$ for the central area of the southern basin of the lake and 0.9 to $1.02 \mathrm{~mm} / \mathrm{yr}$ for areas along the east side of the lake. In agreement with results of studies of the other Great Lakes, the presettlement sedimentation rates in Lake Michigan were generally lower than the postsettlement rates.
\end{abstract}

\section{INTRODUCTION}

Fossil pollen preserved within Lake Michigan sediments reflects changes in the vegetation surrounding the lake. Such changes are well known from studies of the Great Lakes region (Cushing, 1965) and provide one method of determining the age of the sediments. Most vegetation changes took place over thousands of years, however, and short-term fluctuations are not always apparent in the pollen record. One short-term vegetation change that has been correlated and dated throughout the Great Lakes region is a dramatic increase in ragweed (Ambrosia) pollen resulting from the initiation of large-scale forest clearance and agriculture in the middle of the nineteenth century (Davis, Brubaker, and Beiswenger, 1971; Fries, 1962; McAndrews, 1966). Forest clearance started with European settlement

\footnotetext{
* This publication is also Contribution No. 31, Quaternary Studies Center, Illinois State Museum, Springfield, IL 62706.

1 Illinois State Museum, Springfield, Il 62706.

2 Illinois State Geological Survey, Urbana, II 61801.
} 
of the southern part of the Lake Michigan drainage basin about 1840. By determining the depth at which the ragweed increa se starts, a horizon dated at $1840 \mathrm{~A}$. D. can be established for calculating sedimentation rates and for comparing modern pollution levels and sedimentation rates with those of the presettlement period. This paper reports on the analysis of the pollen in four short cores from surficial Holocene bottom sediments of the southern basin of Lake Michigan.

\section{Previous Studies of Pollen in Great Lakes Sediments}

There are few published studies of pollen in Great Lakes sediments, and none has examined the sediments from Lake Michigan. Benninghoff (1962) studied sediments from Lake Superior, but found pollen poorly preserved and sparse. Recent studies of pollen in western Lake Superior (Bruland et al., 1975; Maher, 1975), however, have identified the depth of the ragweed increase and have suggested an increase in sedimentation with the settlement of the Duluth, Minnesota, area. Studies of Lake Erie sediments (Lewis, Anderson, and Berti, 1966) and of surface sediments from Georgian Bay (Anderson and Terasmae, 1966) have found pollen generally well preserved.

The most extensive program of pollen analysis of Great Lakes sediments has been conducted on sediments of Lake Ontario. Analysis of surface sediments from 90 stations on a $16-\mathrm{km}$ grid has resulted in maps showing the pollen content of sediment for the entire lake basin (McAndrews, 1972; McAndrews and Power, 1973). The pollen in Lake Ontario was poorly preserved, the majority of grains being badly corroded, crumpled, and broken. A long core through Holocene and late Wisconsinan sediments within the lake contained pollen assemblage zones which correlate with zones determined for inland lakes in southern Ontario (McAndrews, 1972). From short "Benthos" cores from six stations in deep water, McAndrews (1972) found the increase in Ambrosia starting between 15 and $20 \mathrm{~cm}$ below the surface of the sediment.

Studies of bog and pond sediments on Beaver Island in northern Lake Michigan (Kapp, Bushouse, and Foster, 1969) correlated lake-level fluctuations with the sedimentological history of the island. However, the study did not show an Ambrosia zone near the top of the sediments. Zumberge and Potzger (1956) correlated pollen in a buried peat horizon on the Lake Michigan shore near South Haven, Michigan, with high-water stands of glacial Lake Chicago. The top of this peat section was dated at 4000 radiocarbon years B.P., however; and it did not contain more recent sediments.

In many cases, the pollen found in the Great Lakes sediments is neither well preserved nor abundant, and the thickness of Holocene sediments varies greatly . The poor preservation of pollen, the variability of sediment, and the difficulty of deep-water coring have limited the number of pollen studies in the Great Lakes.

\section{Geology of Southern Lake Michigan}

Lake Michigan began as a proglacial lake more than 13,000 radiocarbon years ago. It occupies a basin carved in Paleozoic bedrock by the Lake Michigan Lobe of the Wisconsinan ice sheet. The lake basin is surrounded by moraines of late Wisconsinan glaciations. The southern one-third of the lake fills one large circular basin in which the water is more than $170 \mathrm{~m}$ deep. A bedrock high separates the southern basin from several smaller basins and intervening ridges in the northern two-thirds of the lake. Four glacial tills underlie the lake (Lineback, 
Gross, and Meyer, 1974). The tills are overlain by glaciolacustrine and lacustrine silts and clays (fig. 1).

In the southern basin, two types of glaciolacustrine sediments overlie the till (Lineback et al., 1971; Lineback, Gross, and Meyer, 1972). The older type is the Carmi Member of the Equality Formation, which consists of silts, sands, clays, and clay-pebble conglomerates that were deposited in close proximity to the glaciers. It is generally thin (less than $1 \mathrm{~m}$ ) except near lake-floor terminal moraines. The younger glaciolacustrine sediment is included in the lower two members of the Lake Michigan Formation, the South Haven and Sheboygan Members; they are reddish gray glaciolacustrine clay derived from the melting of the last ice sheet (Valderan Substage) to occupy the northern half of the Lake Michigan Basin (fig. 1). The Winnetka, Lake Forest, and Waukegan Members are postglacial clays and silty clays derived from sediment carried into the lake by surface drainage and from shoreline erosion (Gross et al., 1972). The Ravinia Member is sand and is confined to the beach areas (Willman and Frye, 1970).

This report on fossil pollen is based on four cores from the southern basin of the lake between Waukegan, Illinois, and Benton Harbor, Michigan (table 1 , fig. 2). Cores 969-2A and 1000-3C are from an area of high Holocene sedimentation rates in intermediate water depths along the east side of the lake (Lineback and Gross, 1972). Core 1001-3A is from deep water, where Holocene sedimentation rates are moderate, and core $1002-3 \mathrm{~A}$ is from the west side, where little Holocene sediment has accumulated. Core 800-5, near core 1001-3A, and core 836-5, which is geologically similar to core 1000-3C, were previously dated by radiocarbon (Lineback and Gross, 1972; Gross, Coleman, and Lineback, 1973).

Circulation of water and air is important to the distribution and deposition of pollen in lake sediments. Water circulation patterns in southern Lake Michigan are complex and seasonal, and interpretation of them is somewhat controversial. Most surface observations indicate that net water circulation affecting sedimentation patterns is generally counter-clockwise and that sediment entering the west side of the lake is swept around to the east side before deposition (Lineback and Gross, 1972; Federal Water Pollution Control Administration, 1967; and Harrington, 1895). Recent studies by Monahan and Pilgrim (1975), however, have produced contradictory evidence indicating that clockwise currents dominated the southern basin during the time of their study. Air movement data collected by the U.S. Weather Bureau at Chicago's O'Hare Airport show that the dominant wind direction is from the southwest and that lesser wind components are from the northwest and

TABLE 1 - CORE LOCATIONS AND WATER DEPTH

\begin{tabular}{|c|c|c|c|c|}
\hline Core no. & $\begin{array}{c}\text { Core } \\
\text { diameter } \\
(\mathrm{mm})\end{array}$ & Latitude & Longitude & $\begin{array}{c}\text { Water depth } \\
(\mathrm{m})\end{array}$ \\
\hline $800-5$ & 120 & $42^{\circ} 25.0^{\prime} \mathrm{N}$. & $87^{\circ} 09.3^{\prime} \mathrm{W}$. & 128.9 \\
$836-5$ & 120 & $42^{\circ} 02.7^{\prime} \mathrm{N}$. & $86^{\circ} 43.5^{\prime} \mathrm{W}$. & 55.5 \\
$969-2 \mathrm{~A}$ & 47 & $42^{\circ} 14.0^{\prime} \mathrm{N}$. & $86^{\circ} 39^{\prime} 2^{\prime} \mathrm{W}$. & 49.9 \\
$1000-3 \mathrm{C}$ & 67 & $42^{\circ} 18.0^{\prime} \mathrm{N}$. & $86^{\circ} 42.0^{\prime} \mathrm{W}$. & 73.4 \\
$1001-3 \mathrm{~A}$ & 67 & $42^{\circ} 22.0^{\prime} \mathrm{N}$. & $87^{\circ} 11.0^{\prime} \mathrm{W}$. & 120.5 \\
$1002-3 \mathrm{~A}$ & 67 & $42^{\circ} 23.0^{\prime} \mathrm{N}$. & $87^{\circ} 34.9^{\prime} \mathrm{W}$. & 70.1 \\
\hline
\end{tabular}


ILLINOIS STATE GEOLOGICAL SURVEY CIRCULAR 496

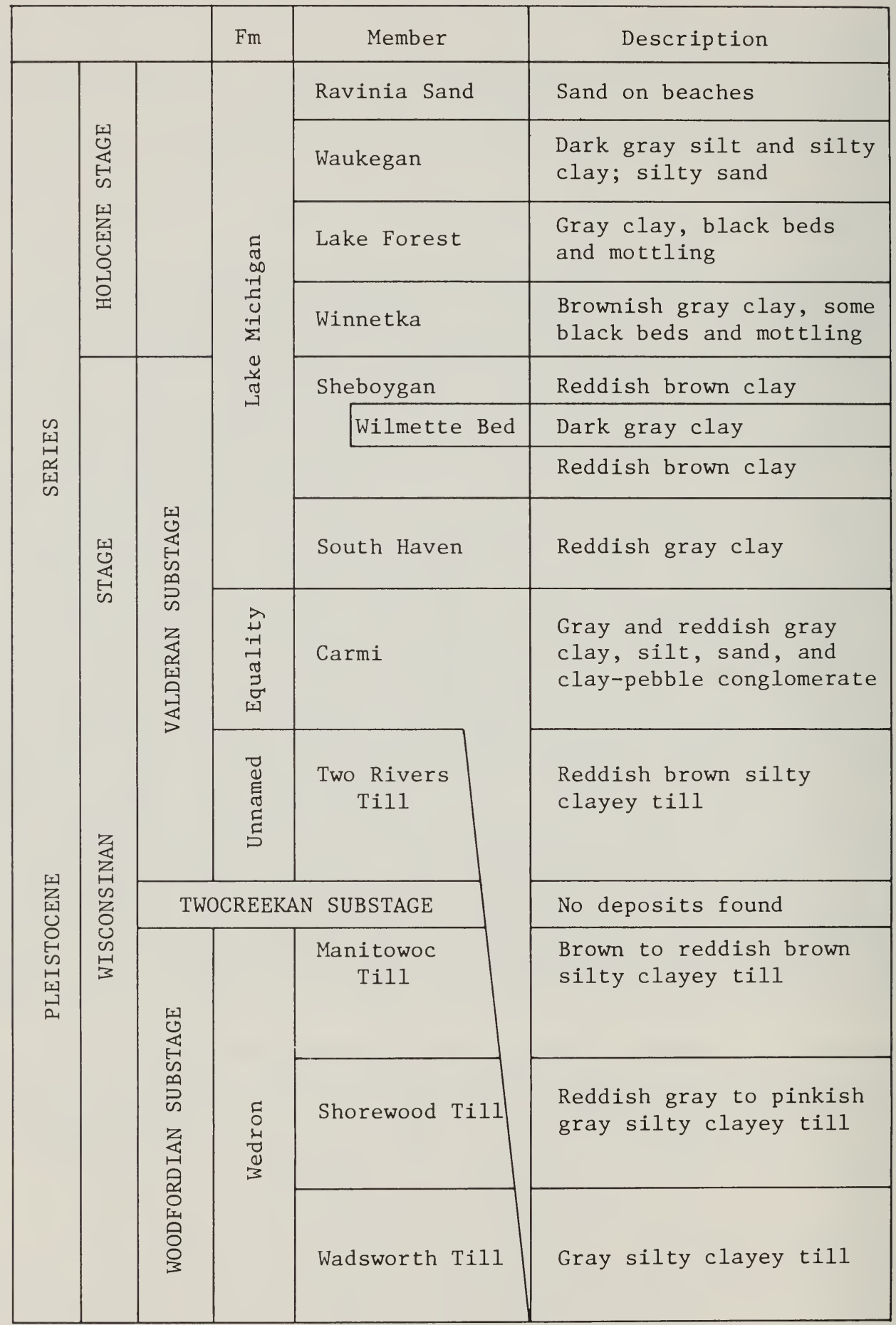

Fig. 1 - Stratigraphic nomenclature for Pleistocene sediments under southern Lake Michigan (from Lineback, Gross, and Meyer, 1974). 


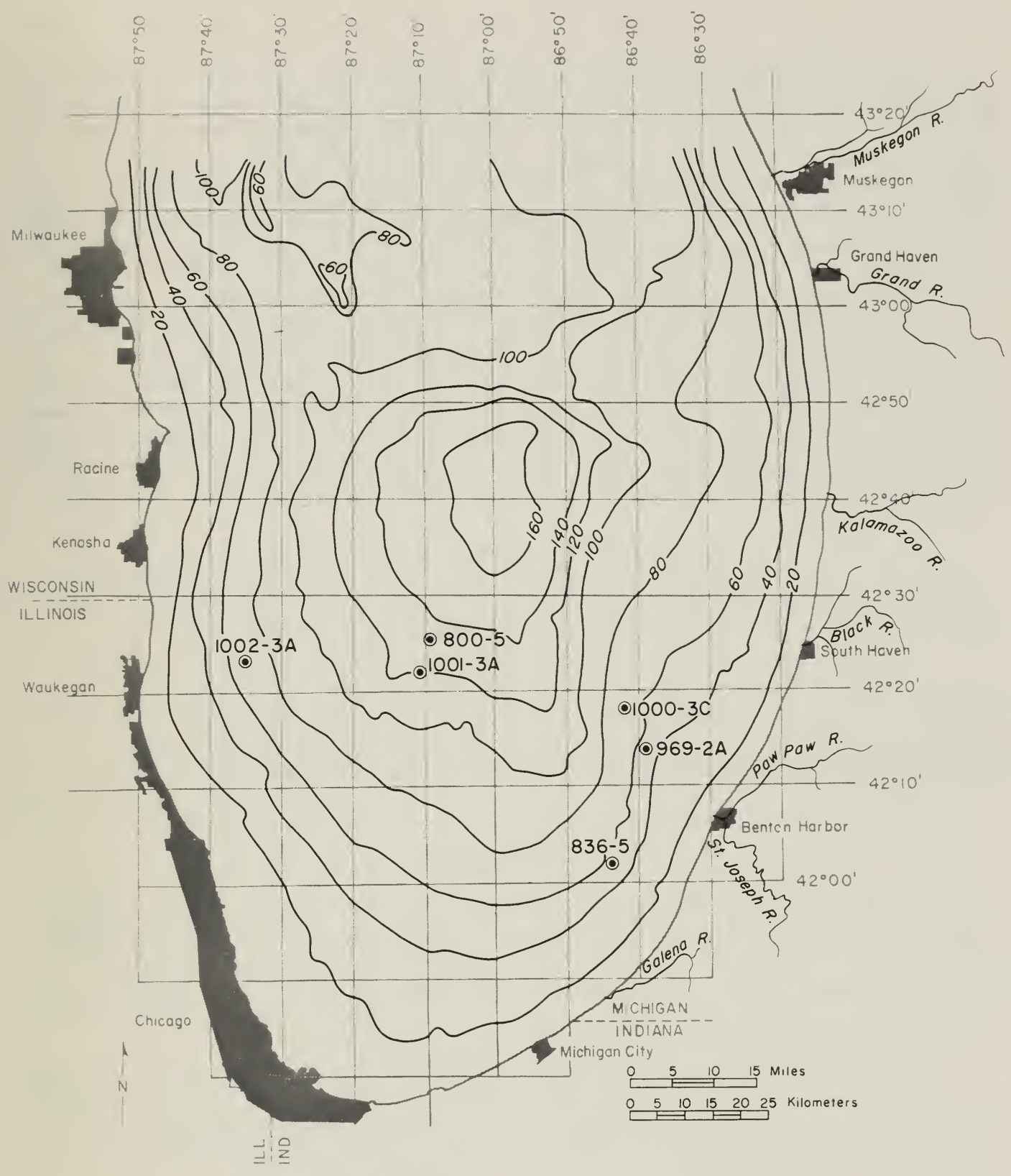

Fig. 2 - Map of southern Lake Michigan showing coring stations, water depth (contour interval $20 \mathrm{~m}$ ), and major tributaries to the lake.

northeast. Southeast winds are uncommon. It is likely that atmospheric circulation patterns throughout the Holocene have been similar to those at present. 
The Vegetation of the Lake Michigan Area

The Lake Michigan drainage area lies within two major forest regions of eastern North America. The northern half of the lake lies within the Great LakesSt. Lawrence division of the Hemlock-White Pine-Northern Hardwoods region, and the southern part lies in the Beech-Maple forest region (Braun, 1950). The Great Lakes-St. Lawrence forest is a mixture of coniferous and hardwood species dominated by pines (Pinus). Locally abundant taxa include oak (Quercus), aspen (Populus), hemlock (Tsuga), spruce (Picea), fir (Abies), maple (Acer), ash (Fraxinus), and birch (Betula). In this region of low relief and glacial topography, drainage is an important control over the local vegetation.

The southern part of Lake Michigan lies within Braun's Beech-Maple forest region. The dominant trees in this area are beech (Fagus) and sugar maple (Acer saccharum). Other locally abundant trees include ash, oak, elm (Ulmus), hickory (Carya), and sycamore (Platanus). Immediately south and southwest of the BeechMaple forest region lies the Prairie Peninsula section, a mosaic of prairie and oakhickory forest. Although the prairie vegetation does not at present border the lake, it probably was an important source of pollen in the lake sediments, especially in early Holocene times.

At present the area bordering the northern part of the lake basin is predominantly forested, whereas the southern part of the lake is bordered by farmland and deforested regions. These areas of intense human use are the source areas for much of the ragweed pollen being deposited at present in the lake.

Lake Michigan drains an area of approximately $117,600 \mathrm{sq} . \mathrm{km}$. The largest rivers in the drainage basin flow into the eastern side of the lake from the lower peninsula of Michigan (fig. 2). As those rivers are major sources of pollen flow into the lake, the pollen record within the lake sediments reflects to a great extent vegetation changes of southern Michigan.

\section{METHODS}

Three 67-mm diameter cores (1000-3C, 1001-3A, and 1002-3A) of bottom sediments were collected with a "Benthos" gravity corer from the R. V. Inland Seas in May 1973 (table 1). These cores were sampled on board ship with a vertical extruder so that the sediments would remain in an upright position and the semifluid mud-water interface would not be destroyed. Generally, the corer caused little disturbance of the delicate surface sediments.

To determine the depth of the initiation of the Ambrosia increase as closely as possible, the upper $20 \mathrm{~cm}$ of each core was removed in $1-\mathrm{cm}$ segments. Below $20 \mathrm{~cm}$, a $1-\mathrm{cm}$ sample was removed every $10 \mathrm{~cm}$. The remainder of the core was saved for radiocarbon analysis. All pollen samples were placed in plastic bags and frozen until processed.

In addition to the 67-mm cores, a 47-mm diameter core (969-2A), which had been collected in October 1972 and stored under refrigeration, was sampled in the laboratory. The upper $5 \mathrm{~cm}$ of sediment in this core, having been disturbed by transportation of the core before it was subsampled, was discarded. The remainder of the core was cut into $2-\mathrm{cm}$ sections to a depth of $1 \mathrm{~m}$; below that depth, 2-cm sections were removed every $10 \mathrm{~cm}$.

Each sediment sample was oven-dried for 24 hours to determine the dry weight of the sediment. The dry weight varied considerably between samples 
even though the samples were of approximately uniform volume. Because of this variation, dry weight rather than sample volume was used for determining pollen concentrations (Fletcher and Clapham, 1974). After the dry weight was obtained, 10 Stockmarr tablets, each containing 12,500 500 Lycopodium spores, were added to each sample (Stockmarr, 1971).

Pollen was extracted from the lake sediments, first by differential settling to remove the heavy particles and then by acid digestion of the remaining inorganic fraction. The carbonates were removed with hydrochloric acid, and the silicates were digested by hydrofluoric acid. The remaining material was treated with a l-minute acetolysis, stained with basic fuchsin, and mounted in glycerin on slides. Counting was done immediately to avoid any problems resulting from pollen swelling due to the glycerin. Calculation of pollen concentrations was made by the Benninghoff (1962) method.

From all but three samples, a total of 200 fossil pollen grains each were counted; 300 grains each were counted from the top three samples of core 1001-3A. The pollen percentages were calculated on the total number of pollen grains counted. The exotic grains (Lycopodium spores) were counted as an outside sum and the fossil pollen concentration in grains per gram dry weight was calculated by the formula

$$
\text { Pollen concentration }=\frac{(125,000) \times \text { (number of fossil grains })}{\text { (number of exotic grains }) \times(\text { g dry } w t)} .
$$

\section{RESULTS}

Diagrams of percentages of pollen were constructed for three cores (1001-3A, 1000-3C, and 969-2A) (figs. 3, 4,6). Diagrams of absolute pollen concentrations were drawn for selected taxa from two cores, for which pollen concentration data were available (figs. 5, 7). Pollen concentration diagrams present the number of pollen grains per gram of dry weight sediment. The use of pollen concentration data avoids the constraints imposed by the relative, or percentage, method. Paleoecological interpretations are usually based on the percentage diagrams, however, because concentration diagrams are not available for most geographic areas. When concentration diagrams are available, they generally confirm the trends in the percentage diagrams.

Most of the pollen in southern Lake Michigan sediments is poorly preserved and badly eroded. Numerous pollen grains exhibit evidence of microbial destruction. Many of them are severely thinned, and others show the characteristic rosette pattern of fungal attack (Elsik, 1971; King, Klippel, and Duffield, 1975). The pollen from the center of the basin is more highly degraded than that from the eastern side. The degradation of pollen in the sediments probably occurred before the sediments were deposited, and it indicates a long period of transportation through surface streams into the lake. However, a number of perfectly preserved grains of delicate types such as Cyperaceae are present in the sediments; and they probably indicate wind transport of some pollen directly into the lake. Several types of Paleozoic spores also were encountered regularly during analysis. These have likely undergone multiple cycles of erosion and redeposition. 


\section{Pollen Assemblage Zones}

Pine and oak pollen dominate throughout percentage diagrams constructed for Lake Michigan cores; in the upper few centimeters, Ambrosia pollen is also abundant. However, presence or absence of pollen taxa is not a major factor in establishing pollen assemblage zones. Rather, zonation relies on subtle changes in percentages of the dominant types and in the numbers of total grains per gram of sediment. The pollen-zone boundaries are not always clearly defined, and they could be shifted several centimeters either way without appreciably affecting the definition of a zone. The important consideration is that these pollen zones are present in all of the cores.

Within the Lake Michigan sediment cores, the following pollen assemblage zones are described:

Zone 4 - The Ambrosia zone is characterized by high percentages of ragweed, low percentages of arboreal pollen, and a high number of total grains per gram. This zone can be divided into two subzones, an early Ambrosia zone (4a), with lower pollen concentrations, and a late Ambrosia zone (4b), with high concentrations, that extends to the present. The base of zone $4 \mathrm{a}$ is defined in this paper as the point at which Ambrosia exceeds 5 percent of the total pollen.

Zone 3 - This zone is characterized by the highest pine percentages in the cores and a high total pollen concentration.

Zone 2 - This zone is characterized by slightly lower percentages of pine and by higher percentages of oak than zone 3 , and by very low pollen concentrations per sample. The numbers of grains per gram in this zone are the lowest encountered in the cores.

Zone 1 - Zone 1 is similar to zone 2 in percentages of oak and pine, but has higher pollen concentrations per sample. The average number of grains per gram is twice that of zone 2. Zone 1 is apparent only in the deeper part of core 969-2A.

To further test the validity of the boundaries between the four pollen assemblage zones, chi-square tests $\left(x^{2}\right)$ of homogeneity were calculated for pairs of adjacent samples (Mosimann, 1965). The counts of Pinus, Quercus, Ambrosia, and Chenopodiineae were used to test the null hypothesis that each of a tested pair of samples was similar to the other. These tests, however, did not take into account the total pollen concentration, which was one of the criteria for visually locating the assemblage zones. Thus, the $\chi^{2}$ tests did not distinguish all of the pollen assemblage zones.

\section{Sediment Cores}

\section{Core $1002-3 \mathrm{~A}$}

The pollen in most of core 1002-3A was quite poorly preserved and was present in such low numbers that counts were not meaningful except for the upper $1 \mathrm{~cm}$, from which a total of 100 exotic grains were counted to determine current pollen deposition on the bottom in the western part of the southern lake basin. The data indicate that 4000 grains per gram are present in the upper $1 \mathrm{~cm}$ of sediments, a low value even for Lake Michigan. 
Core 1001-3A

Core 1001-3A, taken from the center of southern Lake Michigan, penetrated down to the middle of the Sheboygan Member of the Lake Michigan Formation (fig. 2, table 1). However, only enough pollen was present for analysis to a depth of $0.70 \mathrm{~m}$ in the Waukegan Member. Throughout the core, pollen was very sparse and badly eroded. No pollen concentration data are available from this core.

The percentage pollen diagram (fig. 3) shows that the Waukegan Member in core 1001-3A is dominated by pine and oak throughout its length, and that in the upper part significant quantities of ragweed pollen are present. Other tree pollen present include spruce (Picea), juniper (Juniperus), willow (Salix), and ash (Fraxinus). Above $10 \mathrm{~cm}$ there is a greater abundance of such arboreal taxa as fir (Abies), birch (Betula), walnut (Juglans), hickory (Carya), sycamore (Platanus), elm (Ulmus), and maple (Acer) than below. Many of these latter taxa are prevalent in the Ambrosia-dominated sediments above $6 \mathrm{~cm}$ (zone 4). The consistent presence of Platanus in the lake sediments probably reflects the riparian plant communities along the rivers flowing into the lake. These rivers are one of the major means of transporting pollen into the lake system.

The dramatic increase of Ambrosia pollen (zone 4) starts between 6 and 7 $\mathrm{cm}$ below the surface. Below this point ragweed abundance is never more than 8 percent and usually is less than 5 percent. Between $7 \mathrm{~cm}$ and the surface, ragweed increases from 4 percent to 36 percent. The Chenopodiineae, a group of weeds which grow on disturbed land and which include lamb's-quarters (Chenopodium) and pigweed (Amaranthus), also increase in zone 4. Other herbaceous pollen in the core include sage (Artemisia), the tubuliflorae tribe of the Compositae, grass (Gramineae), sedge (Cyperaceae), and an unknown member of the Papilionoideae (legume family).

In addition to the Ambrosia zone (zone 4), the percentage pollen diagram for core 1001-3A can be divided into zones 2 and 3 . Zone 2 lies between $70 \mathrm{~cm}$ and $35 \mathrm{~cm}$. In zone 2 pine averages 20 to 25 percent and oak is approximately 50 percent of the total pollen. The sharp decrease in oak pollen at $50 \mathrm{~cm}$ is not believed to represent a vegetational change. Herbaceous pollens are persistent throughout zone 2. Between $40 \mathrm{~cm}$ and $30 \mathrm{~cm}$, pine increases, and oak and the herbs such as Ambrosia, Gramineae, and Chenopodiineae decrease. Thus a depth of $35 \mathrm{~cm}$ marks the boundary between zones 2 and 3 . The zone of high percentages of pine pollen (zone 3) extends from $30 \mathrm{~cm}$ to $7 \mathrm{~cm}$ in depth and contains pine percentages 15 to 20 percent higher than either zone 2 or zone 4 contains. At the beginning of the Ambrosia increase, zone 4, pine and oak percentages decline.

Chi-square tests identified significant differences at the .95 confidence level between the sample at $30 \mathrm{~cm}$ and the one at $40 \mathrm{~cm}$ and between the one at $3 \mathrm{~cm}$ and the one at $4 \mathrm{~cm}$. The beginning of the Ambrosia rise at 6 to $7 \mathrm{~cm}$ was not identified precisely, because the percentage changes, especially of Ambrosia, are gradual. A significant difference was found between $3 \mathrm{~cm}$ and $4 \mathrm{~cm}$ and may represent the boundary between subzones $4 \mathrm{a}$ and $4 \mathrm{~b}$. However, because the pollen zones are based in part on pollen concentrations, this $\chi^{2}$-determined boundary is not plotted on the pollen diagram (fig. 3).

Core 1000-3C

Core 1000-3C, located on the eastern side of the southern basin (fig. 2, table 1), was taken from the upper part of the Waukegan Member, which is up to $8 \mathrm{~m}$ thick in this part of the basin (Lineback and Gross, 1972). As in the 
LAKE MICHIGAN CORE IOOI-3A

$<1 \%$
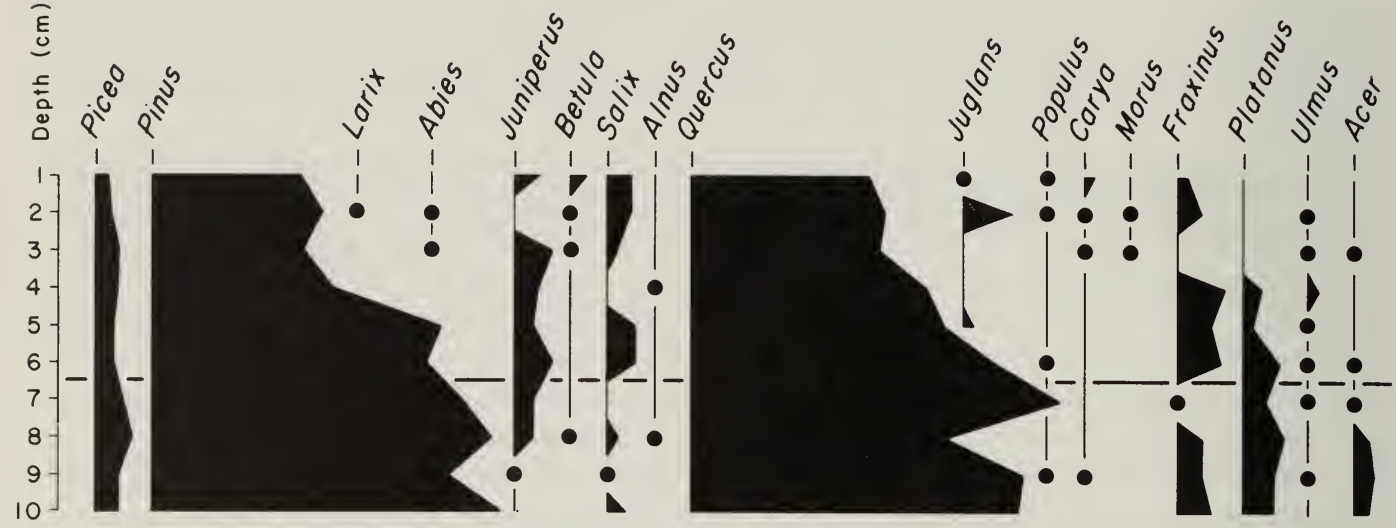

Scale change

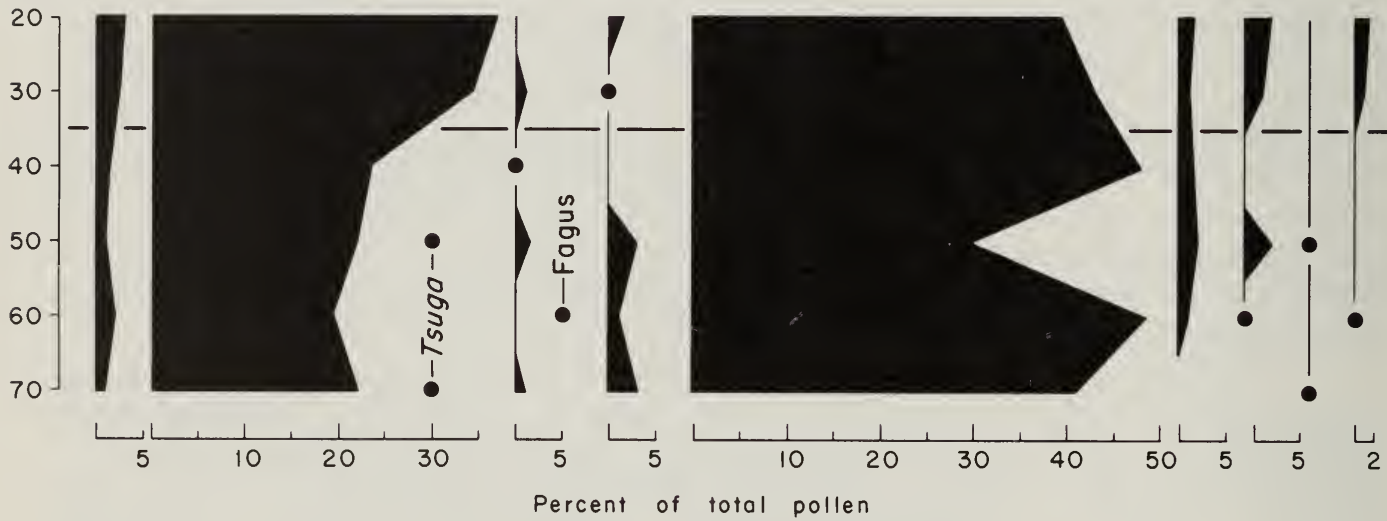

Fig. 3 - Diagram of percentages of pollen for Lake Michigan core 1001-3A.

other cores, the percentage pollen diagram for core 1000-3C (fig. 4) shows a domination by pine and oak throughout the length of the core and by pine, oak, and ragweed in the upper section. Ambrosia starts to increase between $13 \mathrm{~cm}$ and $14 \mathrm{~cm}$ (base of zone 4), rising from 5 percent to 20 percent in this 1 -cm interval. Ambrosia reaches a maximum of 43 percent at $7 \mathrm{~cm}$. There is a similar increase in the Chenopodiineae above $14 \mathrm{~cm}$.

Pollen assemblage zone 2 extends from the bottom of the core to $75 \mathrm{~cm}$ and exhibits low percentages of pine, slightly higher oak percentages than in the higher zone, and pollen concentrations as low as 12,000 grains per gram. At 70 $\mathrm{cm}$, pine concentration abruptly increases by 20 percent, oak concentration declines slightly, and the total pollen concentration increases to 35,000 grains per gram. This shift marks the base of zone 3 , which extends from $75 \mathrm{~cm}$ to $14 \mathrm{~cm}$. Gramineae, Chenopodiineae, and Cyperaceae also decline at this boundary to less than 1 percent each in zone 3 . In the upper part of zone 3 , pine begins to decrease in percentage, oak increases slightly, and ragweed starts to increase.

In zone $4 \mathrm{a}$, pollen concentrations are lower than in either zone 3 or zone $4 \mathrm{~b}$. Throughout zone $4 \mathrm{a}$, concentration of pine declines; concentration of oak 


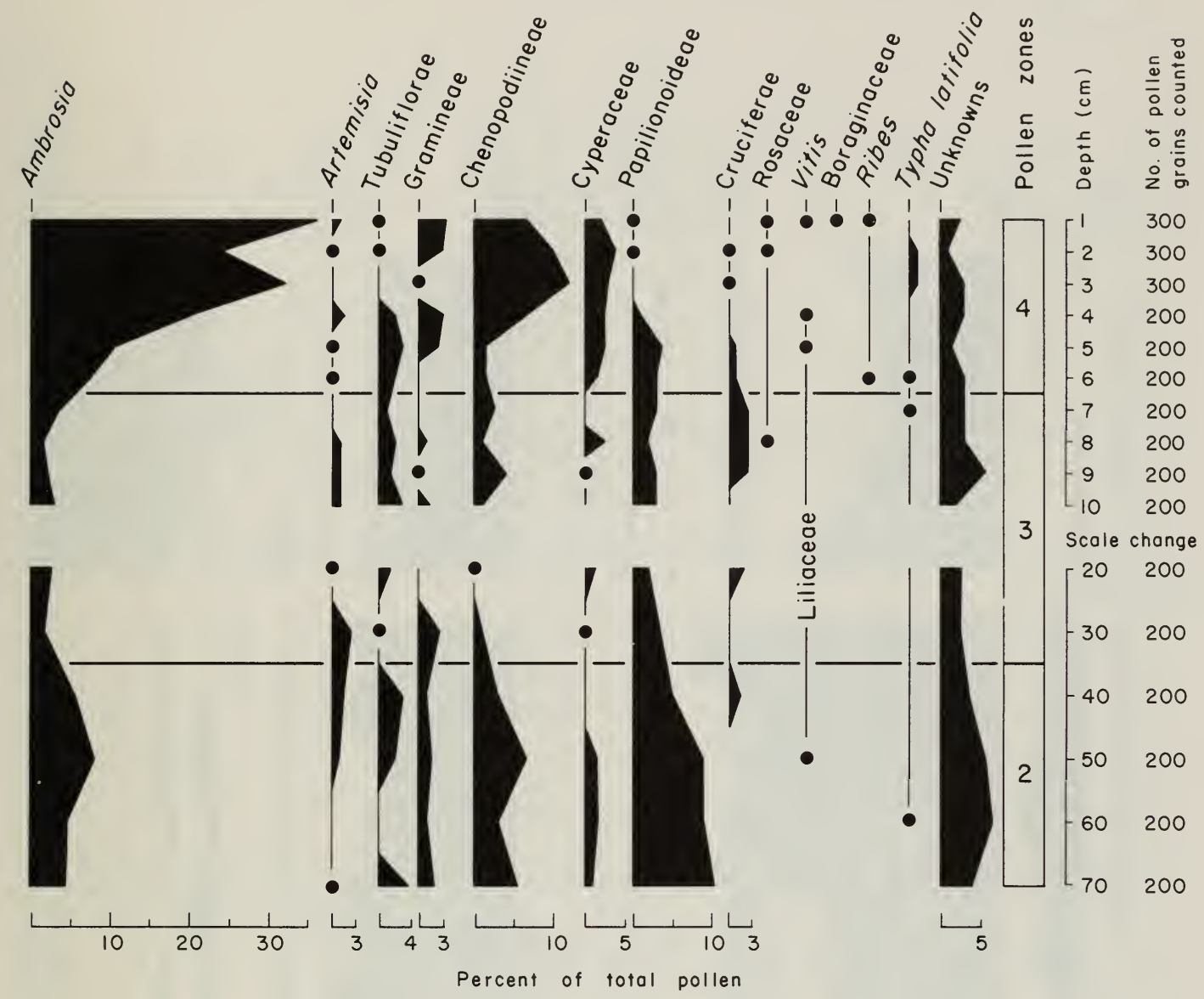

Core collected at $42^{\circ} 22.0^{\prime}$ N., $86^{\circ} 11.0^{\prime} \mathrm{W}$. from 120.5 meters of water.

also declines, but to a lesser extent. With the beginning of the ragweed increase, Gramineae, Chenopodiineae, and Cyperaceae increase. Zone 4b, which extends from $8 \mathrm{~cm}$ to the surface, exhibits a slight decrease and leveling off of ragweed at about 30 to 35 percent and rather constant pine and oak percentages. Pollen concentrations in zone $4 \mathrm{~b}$ reach high values of 91,000 grains per gram.

The pollen concentration diagram of the dominant taxa in core 1000-3C (fig. 5) confirms the trends noted in the percentage diagram. The increase of pine in zone 3 is very prominent. Oak and spruce also increase in concentration in zone 3 , indicating a general expansion of arboreal elements. The decline in numbers of pine and oak grains with the introduction of land clearance and agriculture is abrupt. Pine declines from 29,000 grains per gram of sediment to 5,200 grains per gram and oak declines from 18,000 to 5,000 grains per gram between $20 \mathrm{~cm}$ and $14 \mathrm{~cm}$. Forest clearance was apparently quite extensive in the pollensource areas of these sediments.

The decline in arboreal pollen precedes the increase in ragweed pollen (fig. 5). This sequence suggests that forest clearance and the resulting increase in erosion preceded the buildup of ragweed populations. A similar time lag 
LAKE MICHIGAN CORE IOOO-3C

$\bullet<1 \%$

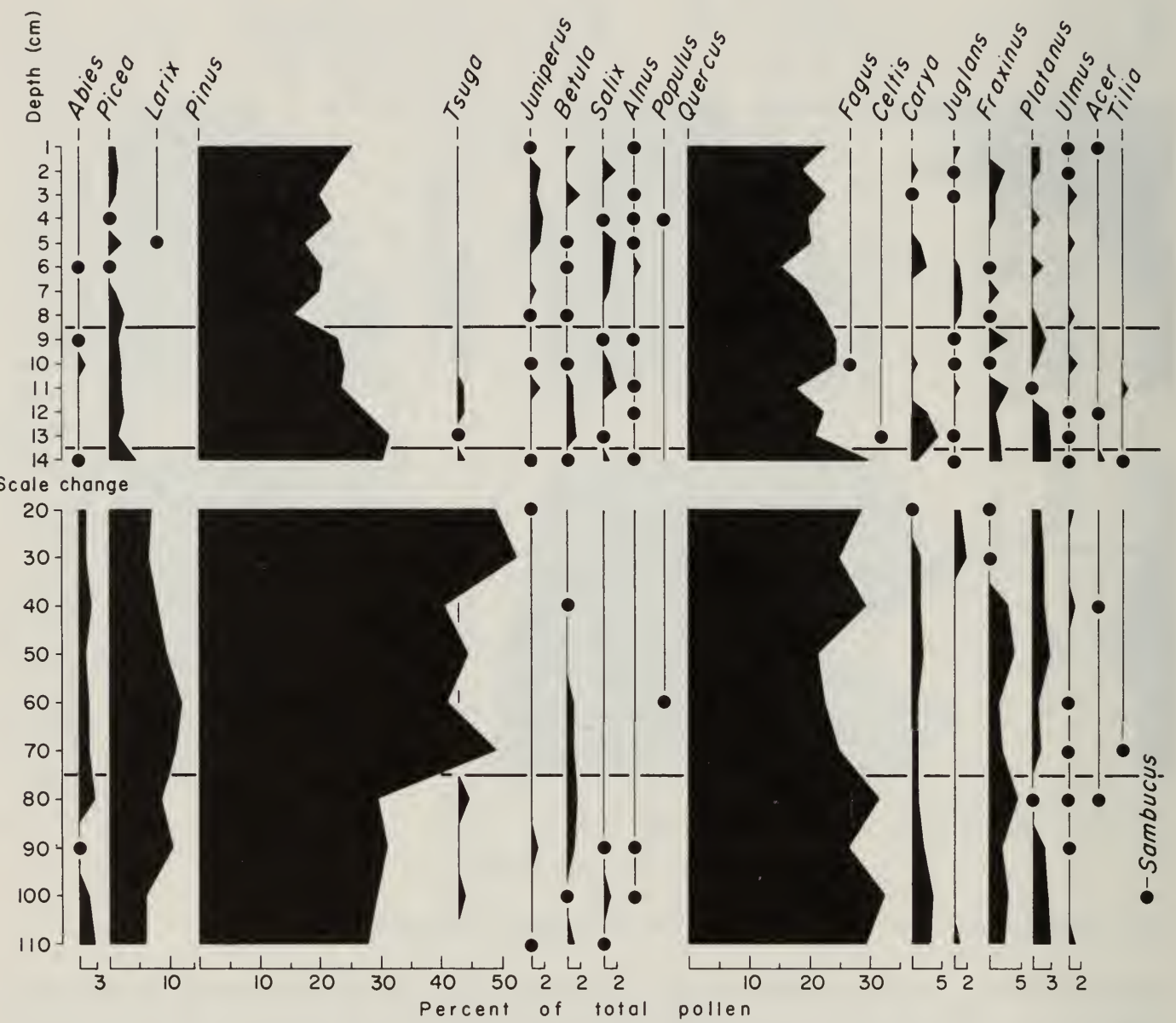

Fig. 4 - Diagram of percentages of pollen for Lake Michigan core 1000-3C. The radiocarbon dates were obtained from residual organic carbon

between logging and the weed increase has been noted in sediment cores from southern Ontario (J. H. McAndrews, personal correspondence, 1974). It is not until zone $4 \mathrm{~b}$ that the pollen concentration approaches its presettlement value and pine and oak regain a prominent place in the pollen record. In zone $4 \mathrm{~b}$, oak increases to its former prominence and pine increases to about half of its previous value. Oak has been more important than pine in the second-growth forests of the Lake Michigan area, and the pollen data reflect this man-made shift in dominance.

Interestingly, the number of ragweed grains per gram has continued to increase since settlement even though the numbers of oak and pine have recovered significantly. This increase possibly reflects changing land-use patterns in the last 130 years. After initial forest clearance, much of it for the timber, agriculturally unprofitable areas were allowed to return to forest, thereby increasing the 


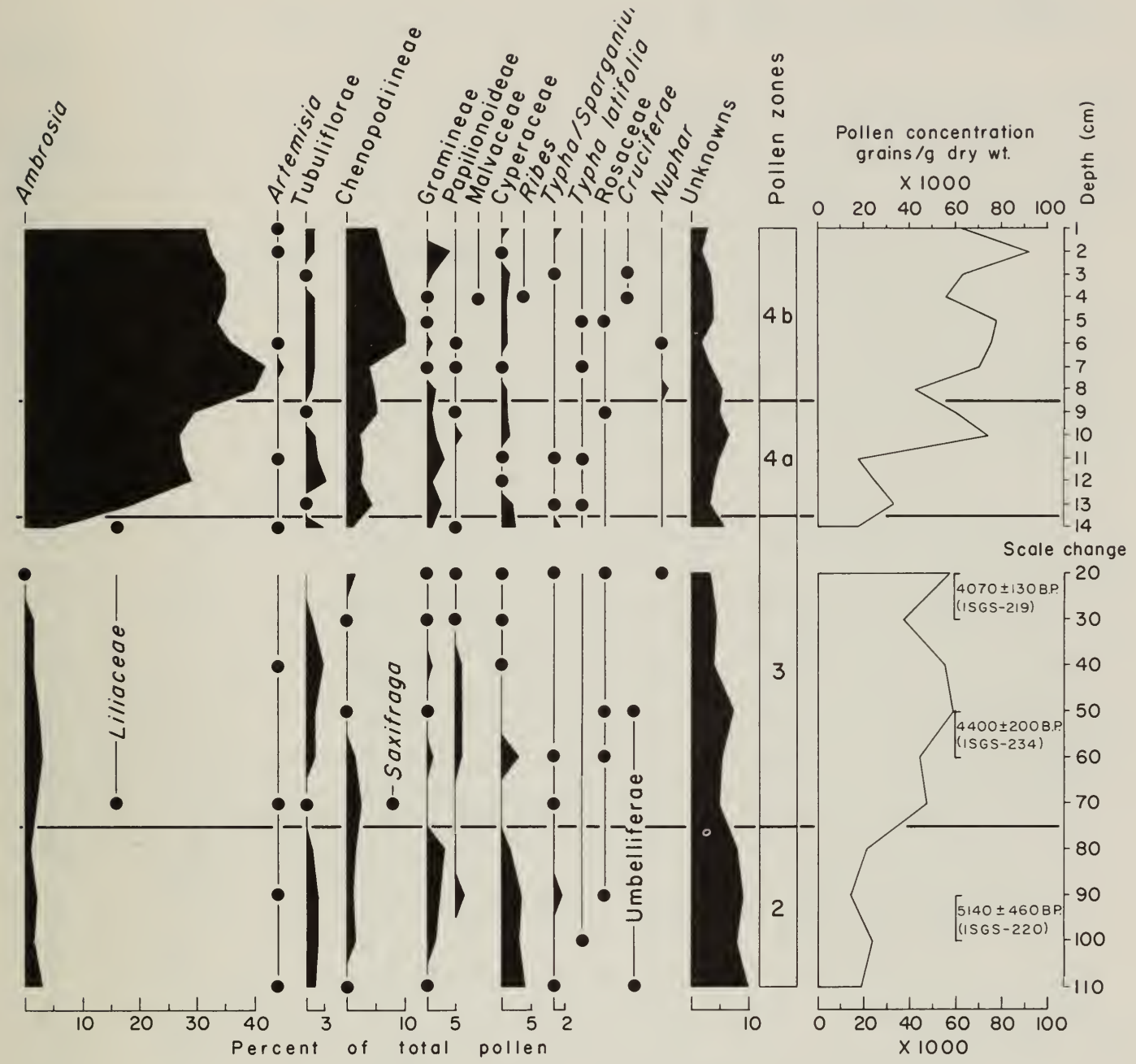

Core collected at $42^{\circ} 18.0^{\prime} \mathrm{N} ., 86^{\circ} 42.0^{\prime} \mathrm{W}$. from 73.4 meters of water.

(see text). 200 fossil pollen grains were counted from each sample.

number of arboreal pollen grains. At the same time, land disturbance in the remaining areas has continued to increase and has produced the steady rise in ragweed pollen shown in the diagrams.

Chi-square tests on adjacent pairs of samples identified significant differences (.95 confidence level) in pollen percentages between the $13-\mathrm{cm}$ and $14-$ $\mathrm{cm}$ samples and between the $75-\mathrm{cm}$ and $80-\mathrm{cm}$ samples. These depths are those previously assigned as the boundaries between zones 3 and $4 \mathrm{a}$, and zones 2 and 3 , respectively. As zone $4 \mathrm{~b}$ is distinguished primarily by increasing pollen concentration, it was not identified by the $\chi^{2}$ tests. 
14 ILLINOIS STATE GEOLOGICAL SURVEY CIRCULAR 496

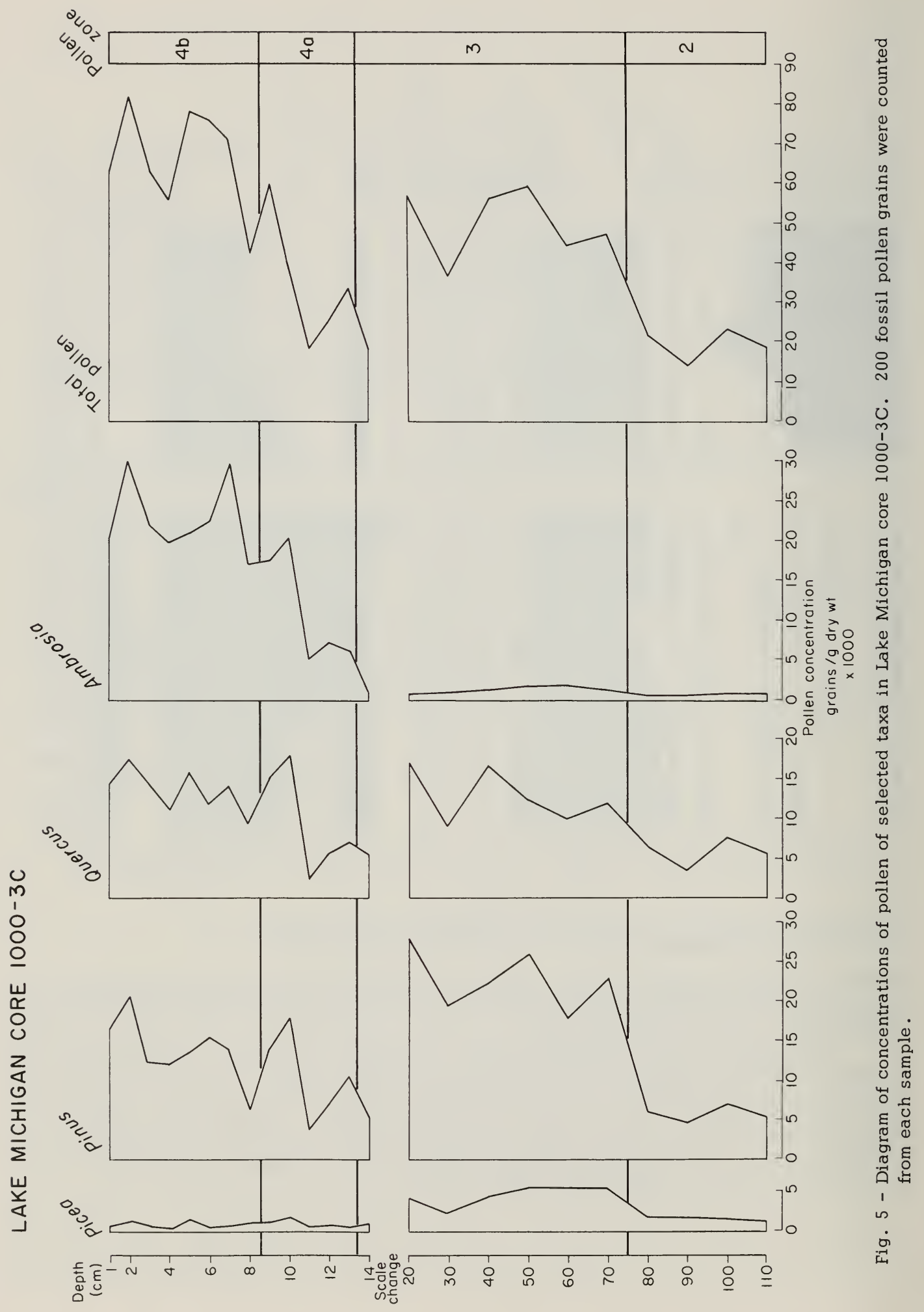


Core 969-2A

Core 969-2A was collected to the north of core 1000-3C; the 3.2-m core was entirely within the Waukegan Member of the Lake Michigan Formation. As noted earlier, the upper $5 \mathrm{~cm}$ of the core was discarded.

The percentage pollen diagram for core 969-2A (fig. 6) resembles the other diagrams in that the pollen assemblage is dominated by oak and pine and it is divisible into the same pollen assemblage zones, with the addition of zone 1 below $230 \mathrm{~cm}$. In zone 1 , the pollen concentration is high and reaches a maximum of 36,000 grains per gram; the percentage of pine declines and the percentage of oak increases toward the boundary of zones 1 and 2 at $230 \mathrm{~cm}$.

Zones 2 and 3 in 969-2A, from the east side of the basin, contain more deciduous tree pollen, especially Platanus, Carya, and Fraxinus, thancore 1001$3 \mathrm{~A}$, which was taken from the center of the lake. This may reflect differential transport or different source areas of these types of pollen. The time required for a pollen grain to reach the center of the basin is unknown, and the buoyancy of the various pollen types could have an important effect on the resulting pollen assemblage deposited on the lake bottom.

Zone 4, which encompasses the Ambrosia increase, starts between 9 and $11 \mathrm{~cm}$ in core 969-2A. The characteristic increase in pollen concentration of zone $4 \mathrm{~b}$ occurs above $7 \mathrm{~cm}$. The boundary between zones 3 and 4 is clearly marked by the increase in Ambrosia. Pine pollen decreases from the middle of zone 3 to the top of the diagram, and oak pollen reaches a peak at the top of zone $3(1 \mathrm{~cm})$, preceding the ragweed increase, and then decreases. The pollen concentration diagram (fig. 7) for core 969-2A shows the decline in arboreal taxa preceding the ragweed rise by $2 \mathrm{~cm}$. The decline in numbers of pine and oak pollen grains in zone 4 is less pronounced in thịs core than in core 1000-3C, but the ragweed increa se is equally large. Ragweed increases from 300 to 20,000 grains per gram between $11 \mathrm{~cm}$ and $5 \mathrm{~cm}$. The number of oak pollen grains increases in the top sample, but that of pine grains does not. The rise in numbers of pine pollen grains in response to reforestation is probably contained within the discarded upper $5 \mathrm{~cm}$ of the core. The largest numbers of oak and pine pollen grains are found in zones 3 and 1 .

The $\chi^{2}$ tests show significant differences in pollen percentages between the sample at $5 \mathrm{~cm}$ and the one at $7 \mathrm{~cm}$ (zones $4 \mathrm{~b}$ and $4 \mathrm{a}$ ), between the sample at $9 \mathrm{~cm}$ and the one at $11 \mathrm{~cm}$ (zones $4 \mathrm{a}$ and 3), and between the one at $230 \mathrm{~cm}$ and the one at $250 \mathrm{~cm}$ (zones 2 and 1). The boundary between zones 2 and 3 was not identified by the $\chi^{2}$ tests, presumably because it is not as clearly defined as in the neighboring core, 1000-3C, and because the pollen concentrations were not considered by the tests. In general, the pollen zones in core 969-2A, especially zones 2 and 3 , are not as distinctive as the zones in the other cores.

\section{Sediment Dating}

The increase in Ambrosia pollen in southern Lake Michigan sediments permits accurate dating of the upper few centimeters of sediment. A wood fragment found between 72 and $94 \mathrm{~cm}$ in core 836-5, near cores 969-2A and 1000-3C, was dated at $910 \pm 140$ (ISGS-100) radiocarbon years B.P. (fig. 8) (Lineback and Gross, 1972). Attempts to date the organic carbon in Lake Michigan sediments have generally yielded dates much older than the wood date. For example, a sample just below the Ambrosia increase in core 1000-3C was dated at $4070 \pm 130$ 
LAKE MICHIGAN CORE 969-2A

$\bullet<1 \%$

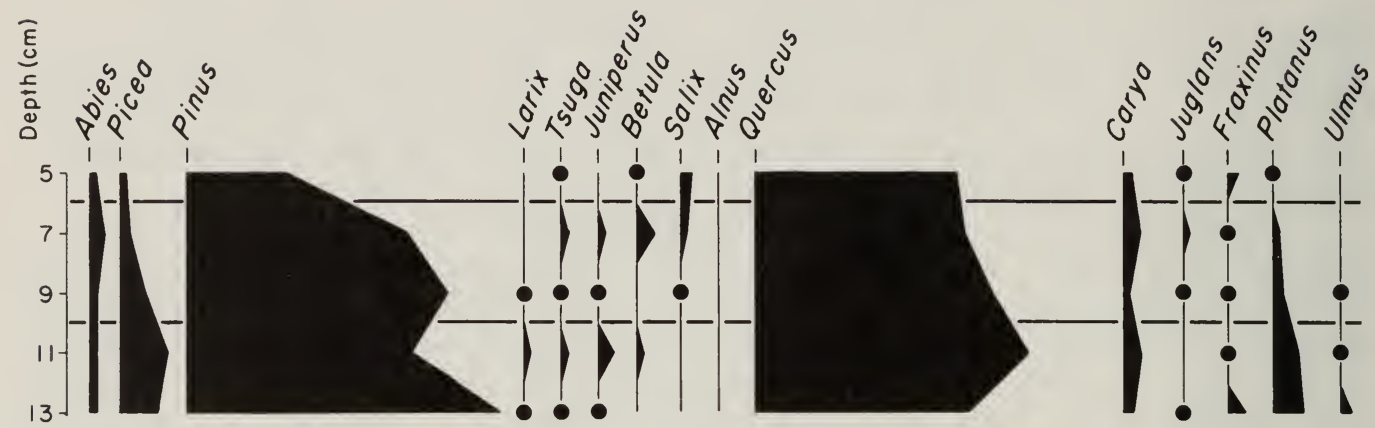

Scale change

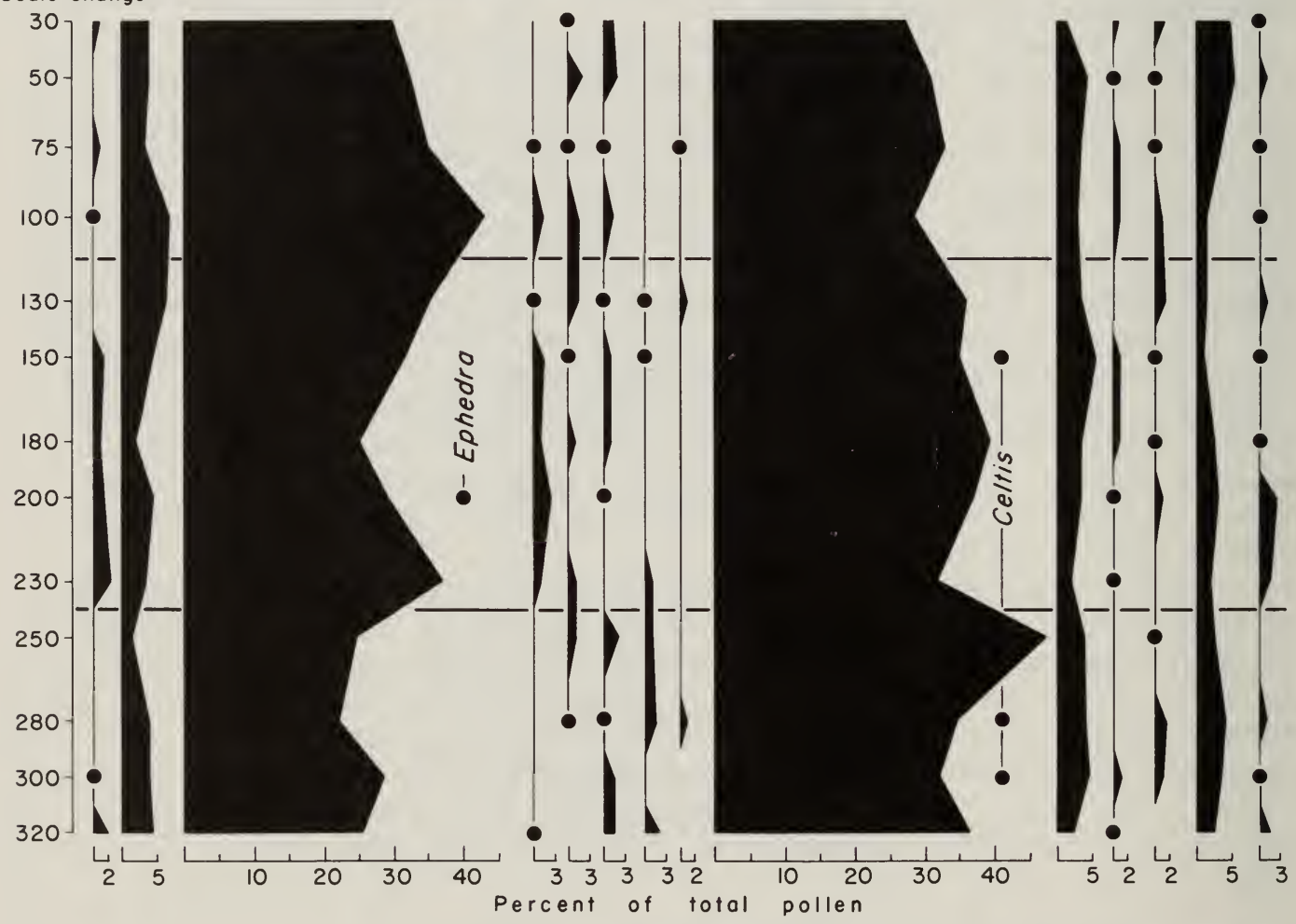

Fig. 6 - Diagram of percentages of pollen for Lake Michigan core 969-2A. 200 fossil pollen grains were counted from each sample.

(ISGS-219) radiocarbon years B.P. (fig. 8). Seven samples from core 800-5, taken near core $1001-3 \mathrm{~A}$, were dated at about 2000 radiocarbon years B.P. at the surface and at more than 7000 radiocarbon years at the 1 -meter level (fig. 9) (Gross, Coleman, and Lineback, 1973). These misleading radiocarbon dates result from the low indigenous organic carbon content of the sediment ( $1 \%$ to $3 \%$ ) and from the likelihood that much of the carbon present is detrital material derived from erosion of the Woodfordian tills around the lake. If the percentage of older 


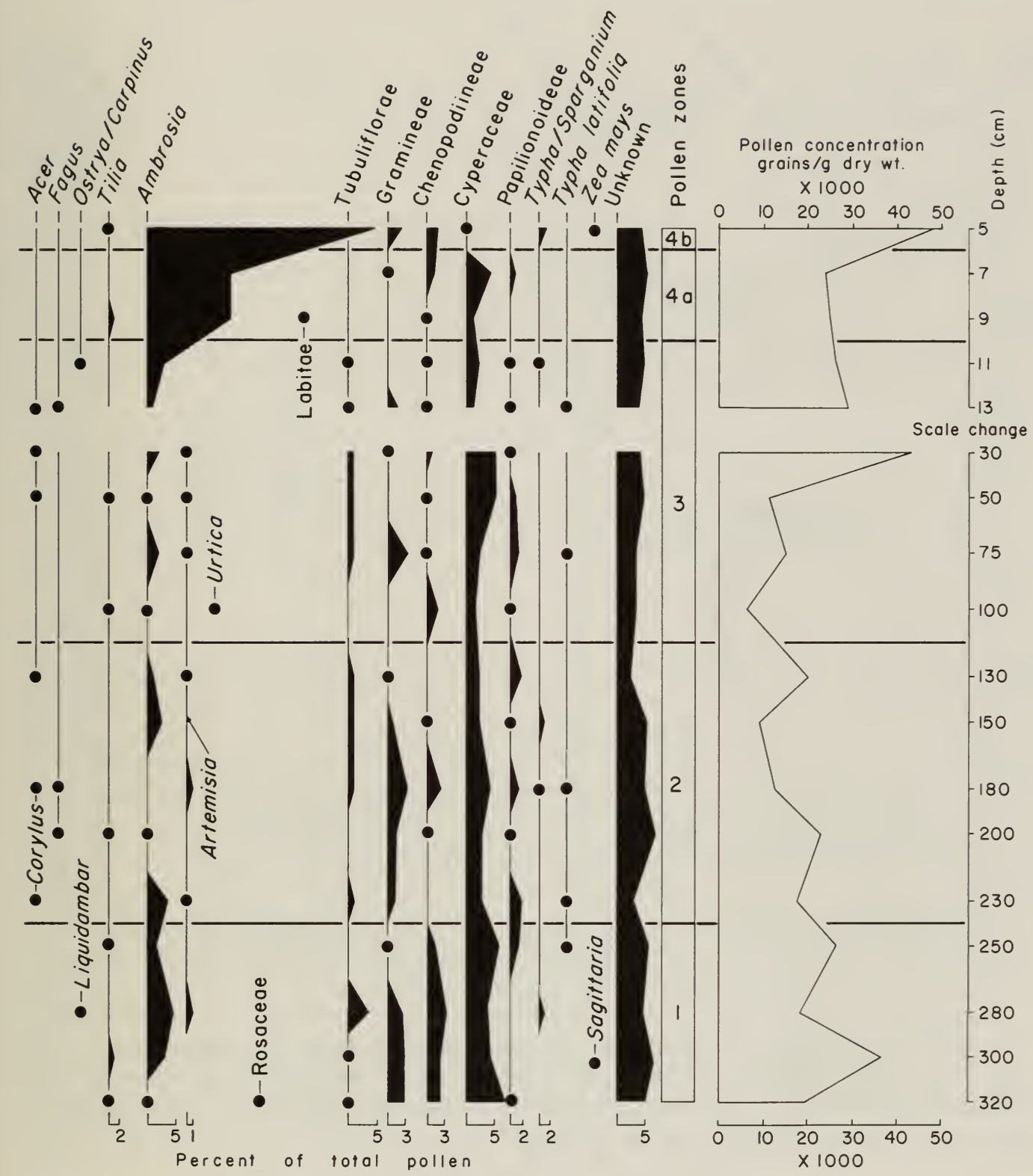

Core collected at $42^{\circ} 14.05^{\prime} \mathrm{N} ., 86^{\circ} 39.2^{\prime} \mathrm{W}$. from 49.9 meters of water.

detrital carbon being deposited in the sediment is constant relative to the percentage of indigenous carbon, these dates can be used to plot sedimentation rate curves. The fact that the radiocarbon dates shown in figure 9 plot in a straight line indicates that the dates are useful for determining sedimentation rates, but not necessarily for determining absolute age.

Cyclic variations in the declination of the geomagnetic field have been discovered in the Lake Michigan sediments (Creer, Gross, and Lineback, 1976). 
LAKE MICHIGAN CORE 969-2A

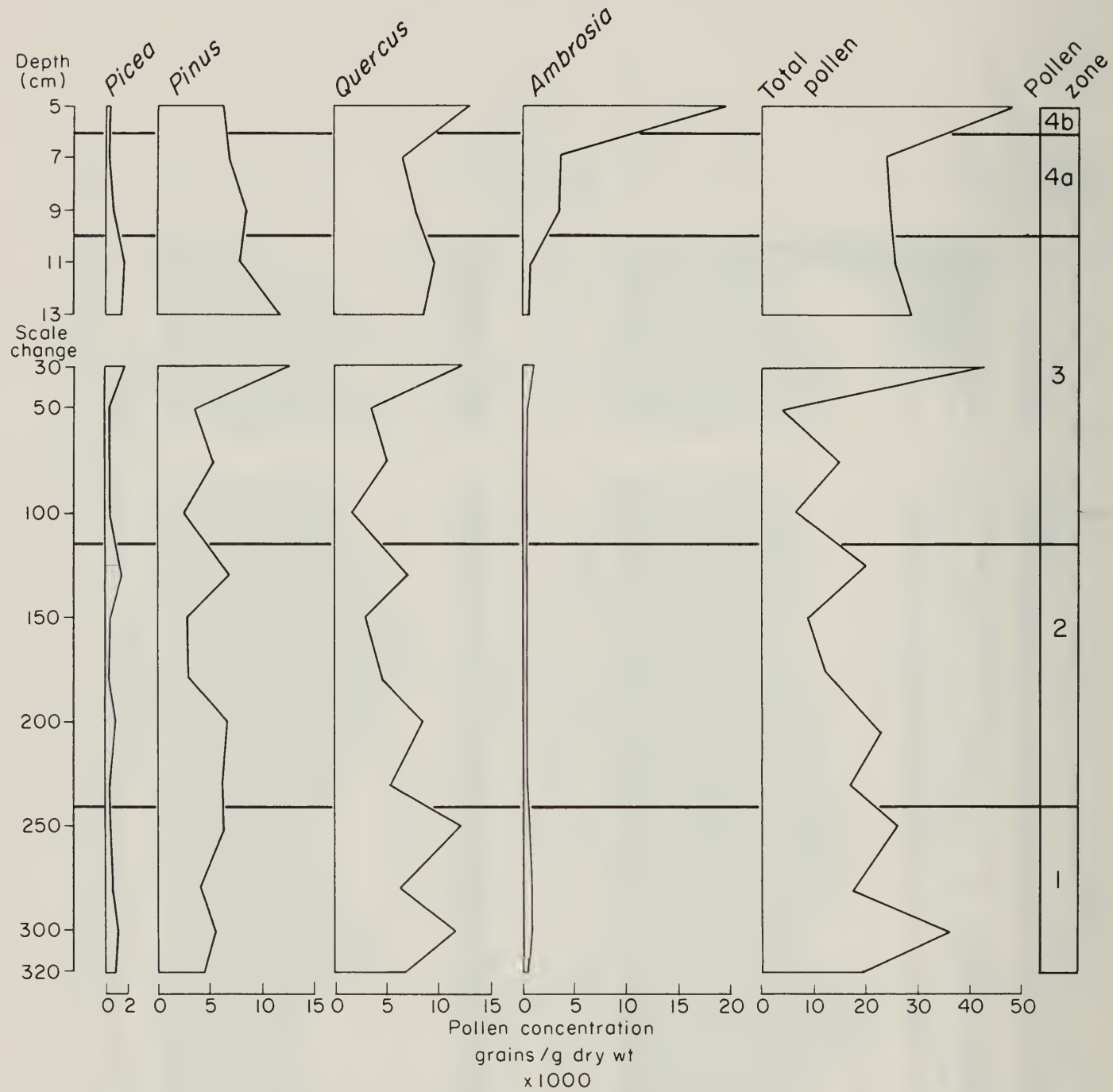

Fig. 7 - Diagram of concentrations of pollen of selected taxa in Lake Michigan core 969-2A. 200 fossil pollen grains were counted from each sample.

On the basis of those cycles, the base of the Waukegan Member has been calculated to be 5540 radiocarbon years B.P.

\section{DISCUSSION}

The pollen preserved in the sediments of southern Lake Michigan record changes in vegetation that have occurred in the region over the last several thousand years. These changes are seen as pollen assemblage zones that are recognizable in both the center of, and the eastern side of, the southern basin of the lake. The increase in Ambrosia pollen in response to a historic land clearance is a particularly important vegetation change in that it provides a time marker independent of radiocarbon or paleomagnetic dating. 


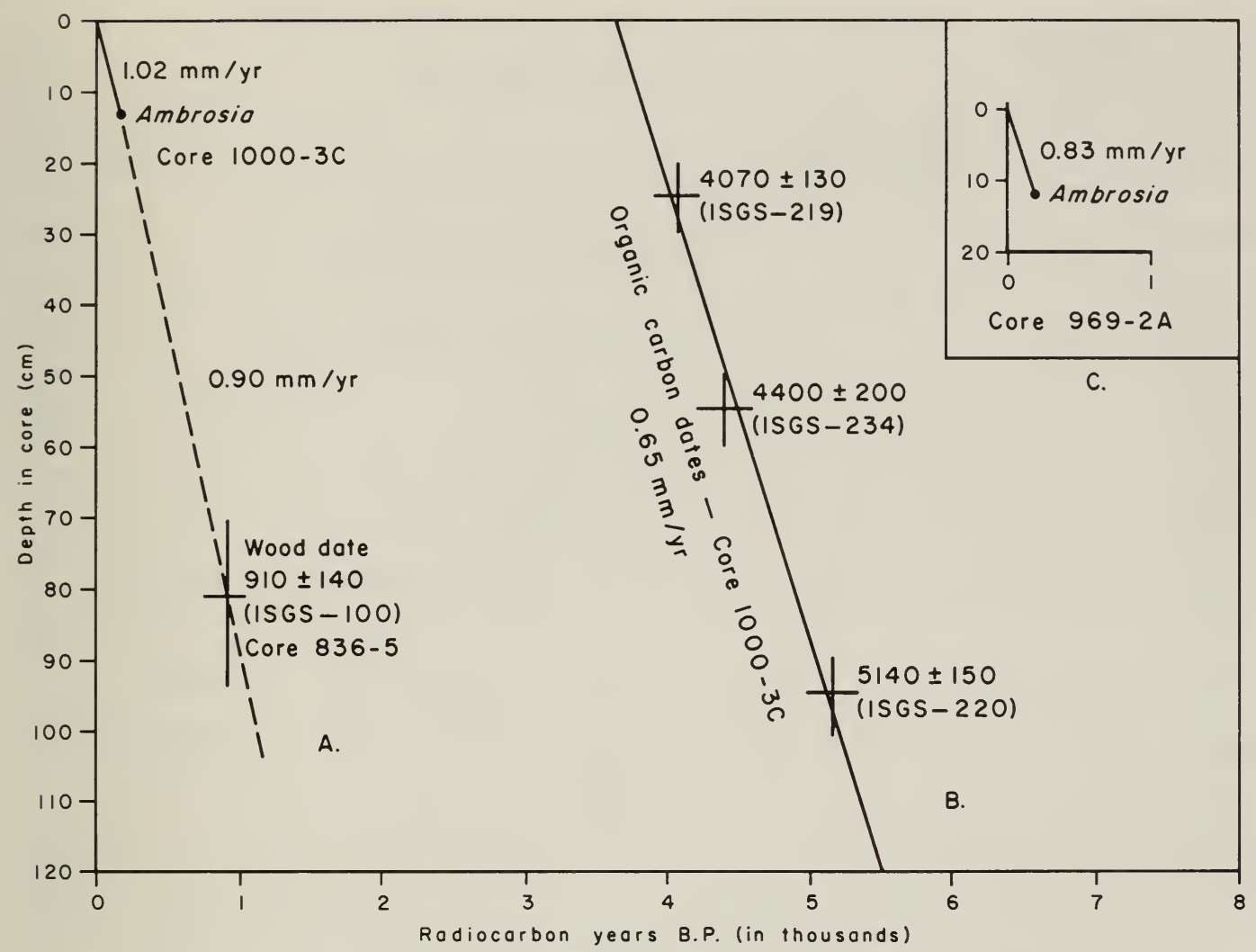

Fig. 8 - Sedimentation rates from eastern Lake Michigan. A. Plot of the depth of the Ambrosia increase in core 1000-3C and a radiocarbon date from core 836-5; B. Plot of the radiocarbon dates from core 1000-3C; C. Plot of the Ambrosia increase in core 969-2A. Rates are determined from the slopes of the lines and are given in $\mathrm{mm} / \mathrm{yr}$.

Developing agriculture and the resulting forest clearance in the Lake Michigan region was a time-transgressive event moving from south to north. The first major land clearing and logging began in southern Michigan in the 1830's and proceeded slowly northward until about 1900 , by which time the vast pine forests of northern Michigan had been destroyed. By 1840 southern Michigan was undergoing extensive forest clearance, and this date is assigned to the beginning of the Ambrosia increase. Varying this date by as much as a decade changes the sedimentation rates by only about 10 percent.

\section{Sedimentation Rates}

Based on the depth of the beginning of the Ambrosia increase, the calculated sedimentation rates for the settlement period (1840 to 1973 ) are $0.83 \mathrm{~mm} / \mathrm{yr}$ in core $969-2 \mathrm{~A}$ and $1.02 \mathrm{~mm} / \mathrm{yr}$ in core $1000-3 \mathrm{C}$, both from the eastern side of the lake (fig. 8), and $0.49 \mathrm{~mm} / \mathrm{yr}$ for core $100 \mathrm{l}-3 \mathrm{~A}$, taken from the center of the southern basin of the lake (fig. 9). Although there was insufficient pollen for analysis in the sediments from the western side of Lake Michigan, geochemical data (Lineback and Gross, 1972) suggest a slow rate of pollen accumulation. A sedimentation rate of less than $0.1 \mathrm{~mm} / \mathrm{yr}$ in the area of core $1002-3 \mathrm{~A}$ is indicated by radiocarbon dates. 


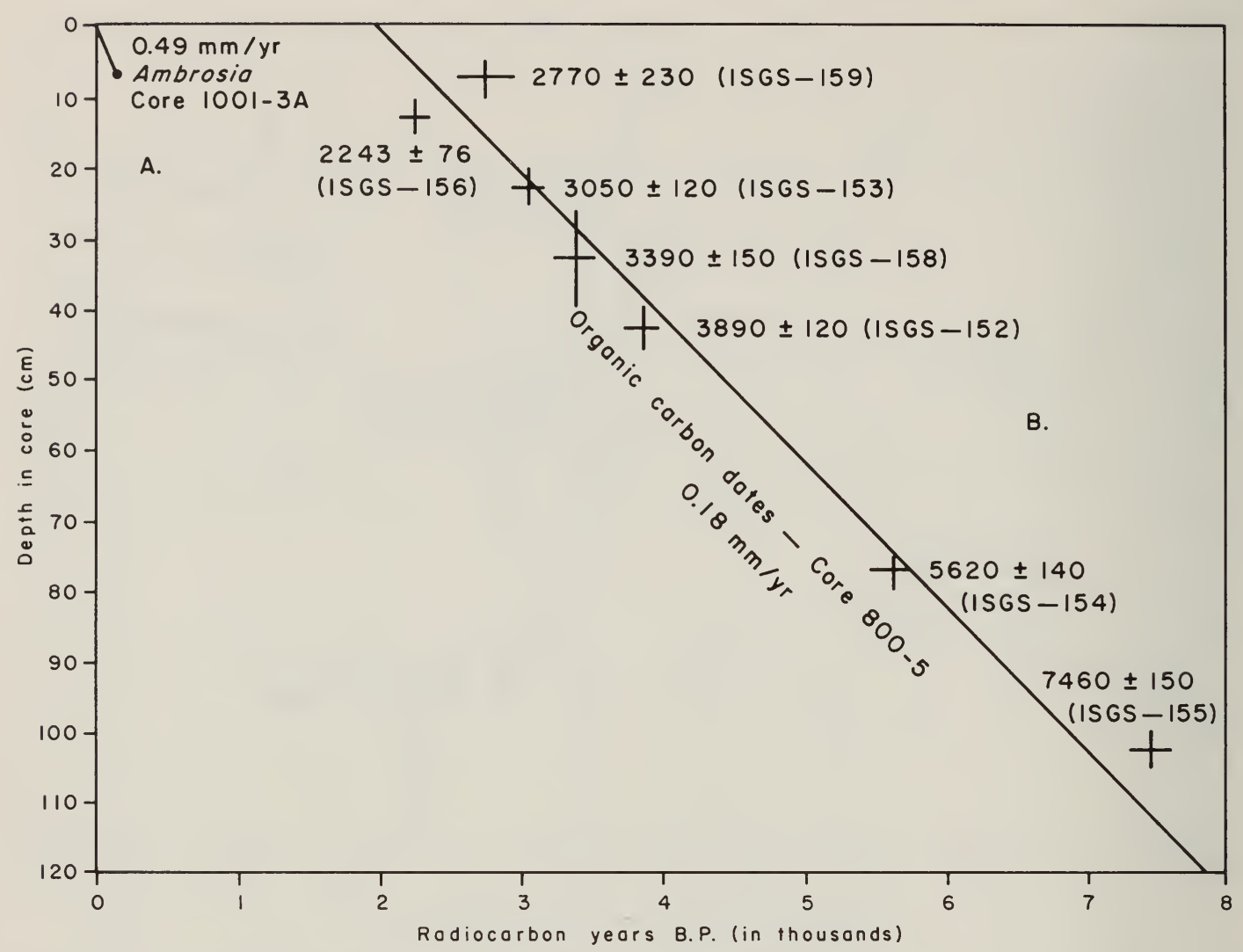

Fig. 9 - Sedimentation rates from central Lake Michigan. A. Plot of the depth of the Ambrosia increase in core 1001-3A; B. Plot of the radiocarbon dates from core 800-5. Rates are determined from the slopes of the lines and are given in $\mathrm{mm} / \mathrm{yr}$.

Late Holocene sedimentation rates calculated for the other Great Lakes show a range of values similar to that found for Lake Michigan. In western Lake Superior, Maher (1975) reported rates of 0.1 to $0.8 \mathrm{~mm} / \mathrm{yr}$. The highest rate was in water $100 \mathrm{~m}$ deep where there was an influx of river sediments. Postsettlement rates in western Lake Superior were as much as 10 times greater than the presettlement rates (Maher, 1975). In Lake Ontario, the beginning of the Ambrosia increase was found at a depth of 15 to $20 \mathrm{~cm}$ in the central basin, an indication of rates of 1.3 to $1.7 \mathrm{~mm} / \mathrm{yr}$, which are significantly greater than the presettlement rates (McAndrews, 1972). Data presented by Kemp et al. (1974) indicate sedimentation rates of $2.3 \mathrm{~mm} / \mathrm{yr}$ for Lake Ontario, 5.8 to $15 \mathrm{~mm} / \mathrm{yr}$ for Lake Erie, and $1.2 \mathrm{~mm} / \mathrm{yr}$ for Lake Huron.

The radiocarbon dates from core 1000-3C plot nearly a straight line with depth (fig. 8) and suggest a sedimentation rate of $0.65 \mathrm{~mm} / \mathrm{yr}$ between $25 \mathrm{~cm}$ and $95 \mathrm{~cm}$. This regression line intersects the zero-depth line at about 3700 radiocarbon years B.P. The wood date of $910 \pm 140$ radiocarbon years B.P. (ISGS-100) from core 836-5 indicates a sedimentation rate of $0.90 \mathrm{~mm} / \mathrm{yr}$. These rates are about the same as, or slightly lower than, the rate since 1840 . Working with $210 \mathrm{~Pb}$, Edgington and Robbins (1976) report sedimentation rates in the same range for southern Lake Michigan. 


\section{Pollen Assemblage Zones and Pollen Abundance}

Comparison of our Lake Michigan pollen diagrams with the work of others on the region is difficult. The pollen assemblage zones apparent within the late Holocene Lake Michigan sediments are not ea sily correlated with those at inland sites, and only a few pollen diagrams are available from southwestern lower Michigan. Several pollen diagrams from the Lake Michigan region, however, do show some trends which may correlate with those seen in our lake diagrams. In Lake Michigan pollen diagrams, the pine maximum (zone 3) below the Ambrosia increase is a common feature. A similar pre-Ambrosia pine peak is seen in the pollen diagram of a core from Kirchner Marsh, southeastern Minnesota, in sediments deposited after 1600 B.P. (Winter, 1962) and in a diagram of a core from the upper sediments of Iola Bog, Wisconsin (Schweger, 1969). Pollen diagrams of cores from central lower Michigan (Gilliam, Kapp, and Bogue, 1967) and eastern lower Michigan (Jones and Kapp, 1972) also exhibit a pine peak immediately preceding the Ambrosia increase. Although it is difficult to determine a date for the pine peak from published diagrams, the peak appears to be a consistent feature immediately preceding the ragweed rise in diagrams of pollen from throughout the Lake Michigan area.

The pollen concentration in the Lake Michigan cores varies from 4,000 to 90,000 grains per gram of sediment. The lowest concentrations are on the west side, the highest on the east side. Before the Ambrosia increase, the highest numbers per gram are found in zone 3 , the zone of the highest pine percentages. The pollen in zone 3 is predominantly arboreal, and it is tempting to speculate about relationships between the increase in numbers of tree pollen grains and the effects of the late stages of the Little Ice Age, or Neoglacial (Flint, 1971, p. 524). Adam (1967) ascribed increasing fir and heath pollen in the top of his pollen diagram from the Sierra Nevada Mountains in California to the effects of this late Holocene period of climatic cooling. Using the regression line plotted from core 10003C (fig. 8, A), zone 3, the pine maximum, falls between 1075 and 130 radiocarbon years B.P. These dates coincide with the late Neoglacial (Denton and Porter, 1970; Porter and Denton, 1967). Wendland and Bryson (1974) have identified 850 B.P. as the time of a "major botanical discontinuity" in North America. Additional support for a climatic cooling during the deposition of zone 3 is shown by the increase in Picea in core 1000-3C. This spruce increase, reflected both in relative abundance (fig. 4) and in pollen concentration (fig. 5), peaks after 1075 B. P., probably at about 800 B.P. Applying the sedimentation rates (fig. 8) to date the other pollen assemblage zones places the boundary of zones $4 \mathrm{~b}$ and $4 \mathrm{a}$ at 71 years B.P. incore 1000-3C. Extrapolating these sedimentation rates to core 969-2A places the boundary of zones 2 and 1 at 2210 years B.P.

The absolute numbers of pollen grains found in Lake Michigan sediments are lower than those reported from Lake Ontario (McAndrews, 1972). In Lake Ontario values as high as 240,000 grains per gram were found, and most samples contained more than 60,000 grains per gram. The low values in Lake Michigan suggest that very little air-borne pollen is settling on the surface of the lake. The major sources of pollen, therefore, may be the rivers that drain into the lake. As most of these rivers are located on the eastern side of the basin, the highest pollen concentrations are found in cores from the east side.

Cores from the east side of the southern basin of Lake Michigan show the highest modern sedimentation rates in the lake (Lineback and Gross, 1972). The base of the Ambrosia increase lies at a depth of 10 to $14 \mathrm{~cm}$ in cores from the 
eastern side of the southern basin and at only $6 \mathrm{~cm}$ in the center of the southern basin of the lake. Man-made pollution, measured by the concentrations of trace elements such as lead, increases upward in the sediments cored. The increase in trace-element concentration towards the surface takes place within the same depth intervals as the Ambrosia increase. Therefore, both the Ambrosia increase and the trace-element concentration increase in the upper few centimeters of Lake Michigan sediments can be related to man's activities since 1840 A.D.

\section{ACKNOWLEDGMENTS}

We appreciate the valuable assistance of Captain Richard Thibault and the crew of the R. V. Inland Seas and of the University of Michigan Great Lakes Research Division, which operated the ship under the sponsorship of the National Science Foundation. Alan Jacobs assisted with the coring and sampling; Rose Duffield and Kent Robinson helped with the laboratory preparation of the pollen samples. We wish to acknowledge Louis J. Maher, F. B. King, and J. Johnson for critically reviewing the manuscript. This work was supported in part by National Science Foundation grant GB-24710 to James E. King.

\section{REFERENCES}

Adam, D. P., 1967, Late-Pleistocene and Recent palynology in the central Sierra Nevada, California, in Cushing, E. J., and H. E. Wright, Jr., eds., Quaternary Paleoecology. New Haven, Conn.: Yale University Press, p. 275-301.

Anderson, T. W., and J. Terasmae, 1966, Palynological study of bottom sediments in Georgian Bay, Lake Huron: Proceedings of Ninth Conference on Great Lakes Research, Chicago, 1966: University of Michigan Great Lakes Research Division Publication 15, p. $164-168$.

Benninghoff, W. S., 1962, Calculation of pollen and spore density in sediments by addition of exotic pollen in known quantities: Pollen et Spores, v. 4, no. 2, p. 332-333.

Braun, E. L., 1950, Deciduous forests of eastern North America. New York: Hafner Publishing Company, $596 \mathrm{p}$.

Bruland, K. W., Minoru Koide, Carl Bower, L. J. Maher, and E. D. Goldberg, 1975, Lead-210 and pollen geochronologies on Lake Superior sediments: Quaternary Research, v. 5, no. 1 , p. 89-98.

Creer, K. M., D. L. Gross, and J. A. Lineback, 1976, Origin of regional geomagnetic variations recorded by Wisconsinan and Holocene sediments from Lake Michigan, U.S.A., and Lake Windermere, England: Geological Society of America Bulletin, v. 87, no. 4, p. 531-540.

Cushing, E. J., 1965, Problems in the Quaternary phytogeography of the Great Lakes Region, in Wright, H. E., Jr., and D. G. Frey, eds., The Quaternary of the United States. Princeton, N. J.: Princeton University Press, p. 403-416.

Davis, M. B., L. B. Brubaker, and J. M. Beiswenger, 1971, Pollen grains in lake sediments: Pollen percentages in surface sediments in southern Michigan: Quaternary Research, v. 1 , no. $4, \mathrm{p} .450-467$.

Denton, G. H., and S. C. Porter, 1970, Neoglaciation: Scientific American, v. 222, no. 6, p. 101-110. Edgington, D. N., and J. A. Robbins, 1976, Records of lead deposition in Lake Michigan sediments since 1800: Environmental Science and Technology, v. 10, no. 3, p. 266-274.

Elsik, W. C., 1971, Microbial degradation of sporopollenin, in Brooks, J., P. R. Grant, M. D. Muir, P. Van Gijel, and G. Shaw, eds., Sporopollenin. London: Academic Press, p. 480-511.

Federal Water Pollution Control Administration, 1967, Lake currents: Water quality investigations, Lake Michigan Basin. Chicago: FWPCA Great Lakes Region, 364 p. 
Fletcher, M. R., and W. B. Clapham, Jr., 1974, Sediment density and the limits to the repeatability of absolute pollen frequency determinations: Geoscience and Man, v. 9, no. 1, p. 27-35.

Flint, R. F., 1971, Glacial and Quaternary geology. New York: John Wiley and Sons, Inc., $892 \mathrm{p}$.

Fries, Magnus, 1962, Pollen profiles of late Pleistocene and Recent sediments of Weber Lake, Minnesota: Ecology, v. 43, no. 2, p. 295-308.

Gilliam, J. A., R. O. Kapp, and R. D. Bogue, 1967, A post-Wisconsin pollen sequence from Vestaburg Bog, Montcalm County, Michigan: Papers of the Michigan Academy of Science, Arts and Letters, v. 52, p. 3-17.

Gross, D. I., D. D. Coleman, and J. A. Lineback, 1973, Sedimentation rates in the deep water areas of southern Lake Michigan: Abstracts, 16th Conference on Great Lakes Research, International Association of Great Lakes Research, p. 123-124.

Gross, D. I., J. A. Lineback, N. F. Shimp, and W. A. White, 1972, Composition of Pleistocene sediments in southern Lake Michigan, U.S.A.: International Geological Congress, 24th Session, Montreal, Section 8, p. 215-222.

Harrington, M. W., 1895, Currents of the Great Lakes as deduced from the movements of bottle papers during the seasons of 1892, 1893, and 1894: United States Department of Agriculture, Weather Bureau, Bulletin B, 6 p.

Jones, C. I., and R. 0. Kapp, 1972, Relationship of Bay County, Michigan, presettlement forest patterns to Indian cultures: Michigan Academician, v. 5, p. 17-28.

Kapp, R. 0., Stephen Bushouse, and Benjamin Foster, 1969, A contribution to the geology and forest history of Beaver Island, Michigan: Proceedings of 12 th Conference on Great Lakes Research, Ann Arbor, Michigan, 1969: International Association of Great Lakes Research, p. 225-236.

Kemp, A. L. W., T. W. Anderson, R. L. Thomas, and A. Mudrochova, 1974, Sedimentation rates and Recent sediment history of Lakes Ontario, Erie, and Huron: Journal of Sedimentary Petrology, v. 44, no. 1, p. 207-218.

King, J. E., W. E. Klippel, and R. Duffield, 1975, Pollen preservation and archaeology in eastern North America: American Antiquity, v. 40, no. 2, p. 180-190.

Lewis, C. F. M., T. W. Anderson, and A. A. Berti, 1966, Geological and palynological studies of early Lake Erie deposits: Proceedings of Ninth Conference on Great Lakes Research, Chicago, 1966: University of Michigan Great Lakes Research Division Publication 15 , p. $176-190$.

Lineback, J. A., and D. L. Gross, 1972, Depositional patterns, facies, and trace element accumulation in the Waukegan Member of the late Pleistocene Lake Michigan Formation in southern Lake Michigan: Illinois State Geological Survey Environmental Geology Note 58, $25 \mathrm{p}$.

Lineback, J. A., D. L. Gross, and R. P. Meyer, 1972, Geologic cross sections derived from seismic profiles and sediment cores from southern Lake Michigan: Illinois State Geological Survey Environmental Geology Note 54,43 p.

Lineback, J. A., D. L. Gross, and R. P. Meyer, 1974, Glacial tills under Lake Michigan: Illinois State Geological Survey Environmental Geology Note 69, 48 p.

Lineback, J. A., D. L. Gross, R. P. Meyer, and W. L. Unger, 1971, High-resolution seismic profiles and gravity cores of sediments in southern Lake Michigan: Illinois State Geological Survey Environmental Geology Note 47, $41 \mathrm{p}$.

McAndrews, J. H., 1966, Postglacial history of prairie, savanna, and forest in northwestern Minnesota: Memoirs of the Torrey Botanical Club, v. 22, no. 2, 72 p.

McAndrews, J. H., 1972, Pollen analyses of the sediments of Lake Ontario: International Geological Congress, 24 th Session, Montreal, Section 8, p. 223-227.

McAndrews, J. H., and D. M. Power, 1973, Palynology of the Great Lakes: The surface sediments of Lake Ontario: Canadian Journal of Earth Science, v. 10, no. 5, p. 777-792.

Maher, L. J., Jr., 1975, Postsettlement sedimentation rates in western Lake Superior based on ragweed pollen abundance: Geological Society of America, Abstracts with Programs (North-Central Section), v. 7 , no. 6, p. 813 .

Monahan, E. C., and P. C. Pilgrim, 1975, Coastwise currents in the vicinity of Chicago, and currents elsewhere in southern Lake Michigan: University of Michigan Technical Report, $160 \mathrm{p}$. 
Mosimann, J. E., 1965, Statistical methods for the pollen analyst: Multinominal and negative multinominal techniques, in Kummel, Bernhard, and David Raup, eds., Handbook of Paleontological Techniques. San Francisco: W. H. Freeman and Co., p. 636-673.

Porter, S.C., and G. H. Denton, 1967, Chronology of Neoglaciation in the North American Cordillera: American Journal of Science, v. 265, no. 3, p. 177-210.

Schweger, C. E., 1969, Pollen analysis of Iola Bog and paleoecology of the Two Creeks forest bed, Wisconsin: Ecology, v. 50, no. 5, p. 859-868.

Stockmarr, Jens, 1971, Tablets with spores used in absolute pollen analysis: Pollen et Spores, v. 13 , no. 4 , p. 615-621.

Wendland, W. M., and R. A. Bryson, 1974, Dating climatic episodes of the Holocene: Quaternary Research, v. 4, no. 1, p. 9-24.

Willman, H. B., and J. C. Frye, 1970, Pleistocene stratigraphy of Illinois: Illinois State Geological Survey Bulletin $94,204 \mathrm{p}$.

Winter, T. C., 1962, Pollen sequence at Kirchner Marsh, Minnesota: Science, v. 138, no. 3539 , p. 526-528.

Zumberge, J. H., and J. E. Potzger, 1956, Late Wisconsin chronology of the Lake Michigan basin correlated with pollen studies: Bulletin of the Geological Society of America, v. 67, no. 3 , p. 271-288.

Illinois State Geological Survey Circular 496

24 p., 9 figs., 1 table, 3000 cop., 1976

Urbana, Illinois 61801 
CIRCULAR 496

ILLINOIS STATE GEOLOGICAL SURVEY URBANA， IL 61801 